\title{
Assessing Efficiency in the Pharmaceutical Sector of
} Nigeria

Efayena O. Obukohwo ${ }^{1}$, Enoh H. Olele ${ }^{2}$ and Patricia N. Buzugbe ${ }^{3}$ The study analyses, empirically, the efficiency of the Pharmaceutical sector in Nigeria. Employing a balanced panel of 20 pharmaceutical firms between 2012 and 2016, the paper uses a non-parametric technique (Data Envelopment Analysis) to analyze the firms' efficiency under the constant returns to scale (CRS) and variable returns to scale (VRS) assumptions. The results obtained shows inefficiency in the pharmaceutical sector as it operates under a decreasing return to scale. This calls for an appropriate policy mix to stimulate the efficiency of the pharmaceutical sector in Nigeria by enhancing research and development (R\&D) as ell as regulations within the sector.

Keywords: Data Envelopment Analysis, Efficiency, Firm, Performance, Pharmaceuticals

JEL Classification: D1, L1.

DOI: 10.33429/Cjas.09218.6/6

\subsection{Introduction}

The pharmaceutical sector in any economy plays a prominent role in the general health of citizens residing in the country. Nigeria is not an exception. Owing to its significance in the general welfare of the economy, it is imperative to give serious attention to issues that concern this sector.

The Nigerian pharmaceutical sector is known to be complex as it involves numerous players (manufacturers, national regulators, wholesalers and retailers, government ministries and other stakeholders). This means that there is need for these stakeholders to put in additional effort to create an enabling environment to exploit the full potentials of the sector. The Pharmaceutical Manufacturers Group of the Manufacturers Association of Nigeria (PMG-MAN, 2010) asserted that the Nigerian pharmaceutical sector has the potential to be a leader in the production and

\footnotetext{
${ }^{1}$ Corresponding author; Department of Economics, University of Nigeria, Nsukka. economix4life@gmail.com.

${ }^{2}$ Department of Economics Delta State University, Abraka, Delta State.

${ }^{3}$ Department of General Studies, Delta State Polytechnic, Oghwashi-Uku.
} 
distribution of pharmaceuticals Sub-Saharan Africa, with nine Nigerian pharmaceutical firms (Drugfield Pharmaceuticals Ltd, Emzor Pharmaceutical Industries Ltd, Evans Medical Plc, Fidson Healthcare Plc, GlaxoSmithKline Nigeria, May \& Baker Nigeria Plc, Mopson Pharmaceutical Industries Ltd, Neimeth International Pharmaceuticals and PZ Cussons Plc) exporting their products to various ECOWAS countries.

Although Nigeria has a large human capital (approximately 190 million people) and vast natural resources, the country is still fraught with poverty, diseases and malnutrition (World Health Organisation, 2013). The World Health Organisation (WHO) rated Nigeria's health sector 187th out of 191 members (WHO, 2000). The poor rating of the sector is due to a lack of standard equipment for production and storage of pharmaceuticals. As such, only a few of the pharmaceutical firms in Nigeria have the capacity to participate in the supply of anti-malaria, anti-TB medicines, anti-retroviral and other pharmaceuticals in international tenders (Lead Capital Ltd, 2008).

Efficiency in the pharmaceutical sector can be measured using: (i) allocative efficiency, (ii) X-efficiency, (iii) distributional efficiency and (iv) technical efficiency coefficients. There are abundant empirical studies on efficiency and its determinants in the pharmaceutical sector of developed economies (Praven and Tapan, 2005; Adhikari, 2005; Jiankang, 2014; Chadda, 2006; Gupta, 2007; Chaturvedi and Chataway, 2006), but there exists a dearth of such studies for developing countries like Nigeria. The growth of the Nigerian Pharmaceutical industry has been featured in few empirical studies, but to the best of our knowledge, a comprehensive work on the efficiency of the industry in a multivariate framework has not been carried out. One of the recent works in this area is that of Wakeel and Ekundayo (2016). Their emphasis however, was on the determinants of the performance of the pharmaceutical industry in Nigeria. This study aims to fill this gap by analyzing empirically, the efficiency of the Pharmaceutical sector in Nigeria using a non-parametric technique (Data Envelopment Analysis) for a balanced panel of 20 pharmaceutical firms between 2012 and 2016. 
The remaining part of the paper is structured as follows; section 2 gives a review of related literature, section 3 provides the methodology; section 4 analyzes the results obtained; and section 5 concludes the study with policy recommendations.

\subsection{Literature Review}

\subsection{Theoretical Literature}

Efficiency can be gauged in relation to a comparison between observed and optimal values of its output and input in the production process. Among the various theories of efficiency, the structure conduct and performance (SCP) model stands out. According to Mari (2009) the SCP model deals with the organization and operation of the free enterprise sector. The framework was derived from taking a neoclassical analysis of markets. It is a combination of empirical studies of industrial experience and economic theories (Giroh, et al., 2010; Shaik, et al., 2009). There are two competing hypotheses in the SCP framework: the traditional "structure performance hypothesis" and "efficient structure hypothesis". While the structure performance hypothesis asserts that the degree of market concentration inversely relates to the degree of competition, both going in opposite directions making concentrated firms to earn higher profits, the efficiency structure hypothesis states that the performance of the firm is positively related to its efficiency.

The efficiency theory has been widely adopted in various empirical studies (Demsetz 1973; Berger, 1995; Howard and Pollock, 1999; Cockburn, 2004; Praveen and Tapan, 2005; Tung, et al., 2010; and Jiankang, 2014). The efficiency hypothesis suggests that the efficiency of a firm dictates the nature of the relationship between the performance of the firm and its structure. Simply put, a firm is said to be highly efficient in relation to close competitors if it can maximize its profit while reducing its current cost structure and current plant size (or expanding its operations). The firm can also be said to be highly efficient if it can minimize its current cost structure. In this hypothesis, the X-efficiency argument holds that firms will have low cost in their production if they possess more productive technologies (Demsetz, 1973; Brozen, 1982; Gale and Branch 1982). The scale efficiency side of the debate states that some firms may be more efficient even though they may have similar technologies and management techniques thus acquiring market shares. 


\subsection{Empirical Literature}

The issue of efficiency has featured in a number of empirical studies (Ferreira, 2014; Lee, 2012; Park, 2012; Behname, 2012; Sahoo and Mishra, 2012; Mensi and Zouari, 2011; Giroh, et al, 2010; Shaik, et al, 2009). For instance, Ferreira (2014) examined the efficiency of the banking industry in the European Union (EU) in relation to market concentration. Mishra and Vikas (2010), using a modified structure conduct and performance (SCP) model, explored 176 pharmaceutical firms and arrived at the conclusion that there is a bi-lateral relationship between performance and conduct variables in the selected firms. The findings of the study of Ferreira (2014) complemented that of Lee (2012) who examined the model in the Taiwanese CPA industry.

On their part, Mishra and Chandra (2010) employed the data of 52 pharmaceutical firms in India in search of a measure of efficiency. Their results showed that increasing the selling measures (for example via advertisements and promotions) will lead to a positive and significant impact on the profit level of the firms. Sarita, et al (2012) adopted the same model in their examination of the Indonesian banking industry. While Sahoo and Mishra (2012) explored efficiency in the Indian banking industry, Maudos (1998) examined efficiency in the banking sector of Spain. Though the study adopted efficient structure hypothesis, the findings corroborated some of the findings of previous studies on the subject area.

While the majority of literature that adopted SCP model is found in the developed economies and mostly in the banking sector of such countries (Ferreira, 2014; Behname, 2012; Sahoo and Mishra, 2012; Park, 2012; Lee, 2012; Mensi and Zouari, 2011; Maniatis, 2006), few studies were conducted on pharmaceutical firms operating in developing economies (Vyas, et al. 2012; Mishra and Chandra, 2010; Mishra and Vikas, 2010; Zhang \& Li, 2009). Ogaji et al (2014) showed that the capacity utilization of the Nigerian pharmaceutical industry increased steadily but marginally over the period of 1984 to 2014.Furthermore, Ugbam and Okoro (2017) asserted that larger firms are more efficient in the pharmaceutical industry in Nigeria. This implies that smaller firms faced with stiff competition from rival firms will eventually wind up (Olugbenga, 2010). 


\subsection{Methodology}

\subsection{The Data Envelopment Analysis (DEA)}

There exist numerous techniques (statistical and econometrical) adopted in both theoretical and empirical consideration of efficiency. However, in recent years, the Data Envelopment Analysis (DEA) has become more popular $(Z h u, 2002)^{1}$.

The Data Envelopment Analysis (DEA) method was proposed by Charnes et al., (1978). Analytically, this methodology employs linear programming to generate an efficient frontier and related efficiency indicators within homogeneous production units. DEA is a nonparametric method which measures economic efficiency. It is a linear programming model, assuming no random mistakes, used to measure technical efficiency. In relation to a firm, an efficient firm is one that produces a certain quantity of output given a stipulated quantity of inputs. It can also be expressed as the use of the same quantity or less inputs to produce a given amount of output compared to other firms in a given strata. This technique has been explored in many fields including environmental, financial, security, power, and administration (Kwon and Lee, 2015; Tao et al, 2013; Tsolas and Charles, 2015; Wanke and Barros, 2014; Aristovnik et al, 2014; Fang and Li, 2015; Du et al, 2014; Lozano, 2015; Azadeh et al, 2015; Omrani, et al, 2015). The technique is used to evaluate performance across a set of homogeneous production units with multiple resources and products. From the foregoing, the Nigerian pharmaceutical industry constitutes the Decision-Making Units (DMUs), which can be treated as multiproduct firms that transform resources (inputs) into products (outputs). By adopting the DEA, we seek to find the DMUs that produce the highest output levels by using the lowest input levels. The desired efficiency level of $100 \%$ can only be achieved if none of the inputs or outputs can be improved without worsening some of its other inputs or outputs.

In the Charnes, Cooper and Rhodes (CCR) model proposed in 1978, there are $\mathrm{n}$ DMUs to be evaluated, and each $\operatorname{DMUj}(\mathrm{j}=1, \ldots, \mathrm{n})$ has $\mathrm{m}$ inputs (resources) and s outputs (products), which are denoted with the vectors $x j=(x 1 j, \ldots, x m j) T$ and $y j=(y 1 j, \ldots, y s j) T$, respectively. It should be noted that the focus here is that of measuring relative efficiency. DEA seeks to maximize the scalar measure 
of efficiency $(e 0)$ of the $D M U 0$, as shown below;

$$
\max _{\mu \omega} h_{0}=\frac{\sum_{r=1}^{s} \mu_{r} y_{r} 0}{\sum_{i=1}^{m} \omega_{i} x_{i 0}}
$$

subject to

$$
\begin{gathered}
\frac{\sum_{r=1}^{s} \mu_{r} y_{r j}}{\sum_{i=1}^{m} \omega_{i} x_{i j}} \leq 1 ;(j=1, \ldots, n) \\
\frac{\mu_{r}}{\sum_{i=1}^{m} \omega_{i} x_{i 0}}>\epsilon ;(r=1, \ldots, s) \\
\frac{\omega_{r}}{\sum_{i=1}^{m} \omega_{i} x_{i 0}}>\epsilon ;(i=1, \ldots, m) \\
\epsilon>0 \mu_{r}, \omega_{r} \geq 0(r=1, \ldots, s \text { and } i=1, \ldots, m)
\end{gathered}
$$

where $\omega_{i}$ and $\mu_{r}$ represent $i-t h$ input and $r-t h$ output weights for $D M U_{0}$.

The model above is designed to evaluate the relative performance of some decision making unit (DMU), designated as $D M U_{0}$, based on observed performance of $j=1,2, \ldots, n$ DMUs. A DMU is to be regarded as an entity responsible for converting inputs into outputs.

The $y_{r j} ; x_{i j}>0$ in the model are constants which represent observed amounts of the $r^{\text {th }}$ output and the $i^{\text {th }}$ input of the $j^{\text {th }}$ decision making unit which can be referred to as $D M U_{j}$ in a collection of $j=1, \ldots, n$ entities which utilize these $i=1, \ldots, m$ inputs and produce these $r=1, \ldots, s$ outputs. The numerator of the above expression represents a set of desired outputs and the denominator represents a collection of resources used to obtain these outputs. The value $h 0^{*}$ obtained from this ratio satisfies $0 \leq h 0^{*} \leq 1$ and can be interpreted as an efficiency rating in which $h 0^{*}=1$ represents full efficiency and $h 0^{*} \leq 1$ means inefficiency is present. The sign $\left(^{*}\right)$ indicates an optimal value obtained from solving the model. It is assumed that $h 0^{*}$ is invariant to the units of measure used for the input and 
output variables. It is also assumed that the data is non-negative and that each DMU has at least one positive input and output value.

In this regard, Scale Efficiency (SE) measures the impact of the operating scale on DMU productivity, and is defined as shown below:

$$
\begin{gathered}
S E \text { of } D M U=\frac{\text { Technical Efficiency of } D M U_{0}}{\text { Pure Technical Efficiency of } D M U_{0}} \\
S E \text { of } D M U=\frac{C C R \text { Efficiency of } D M U_{0}}{C C R \text { Efficiency of } D M U_{0}}
\end{gathered}
$$

Given the above equation, the technical efficiency of a DMU can never exceed its pure technical efficiency. In this way, the overall efficiency or technical efficiency (CCR) can be decomposed as follows:

$$
C C R=B C C * S E
$$

The CCR model calculates the technical efficiency (TE), which measures the success of a DMU in producing as large outputs from a given set of inputs (Farrell, 1959). Whereas the BCC model according to Kumar and Gulati (2008), calculates the pure technical efficiency.

The decomposition expressed above is unique as it indicates the source of inefficiency. In other words, it describes if the inefficiency is caused by inefficient operation (BCC) or unfavorable circumstances (SE). In some cases, it could be caused by both factors. It should be noted that the scale efficiency measures the gap between the efficiency score of a DMU under the Constant Returns to Scale (CRS) and Variable Returns to Scale (VRS) assumptions. In the CRS assumption, it is assumed that the firms are operating at an optimal level, while in the VRS, the firm is assumed to be operating below optimal level.

As required by this study, we adopted the Malmquist Productivity Index (MPI) first introduced by Fare et al. (1994), to evaluate the efficiency changes between two time periods. The index is given as:

$$
M P I_{0}^{t, t+1}=\left[\frac{D_{0}^{t}\left(X^{t+1}, y^{t+1}\right)}{D_{0}^{t}\left(X^{t}, y^{t}\right)} * \frac{D_{0}^{t+1}\left(X^{t+1}, y^{t+1}\right)}{D_{0}^{t+1}\left(X^{t}, y^{t}\right)}\right]^{\frac{1}{2}}
$$


where $M P I_{0}^{t, t+1}$ is the Malmquist productivity index with output orientation, $y$ represents the output vector that can be obtained with the resource vector $x$, and $D_{0}$ denotes the distance function. The MPI can be decomposed into technical efficiency changes and technological frontier changes, in the following way:

$$
M P I_{0}^{t, t+1}=\left[\frac{D_{0}^{t+1}\left(X^{t+1}, y^{t+1}\right)}{D_{0}^{t}\left(X^{t}, y^{t}\right)}\right]\left[\frac{D_{0}^{t}\left(X^{t+1}, y^{t+1}\right)}{D_{0}^{t+1}\left(X^{t+1}, y^{t+1}\right)} * \frac{D_{0}^{t}\left(X^{t}, y^{t}\right)}{D_{0}^{t+1}\left(X^{t+1}, y^{t+1}\right)}\right]^{\frac{1}{2}}
$$

Where the first parenthesis measures technical efficiency change (TEC) between period $t$ and $t+1$, the geometric mean of the two ratios in the second parenthesis measures production frontier change (FC) between two time periods. From the foregoing, Malmquist index is expressed as:

$$
T E C_{0}^{t, t+1} * F C_{0}^{t, t+1}
$$

Thus, $T E C_{0}^{t, t+1}$ relates to the level of effort that the DMU has been to achieve efficiency, and measures the capacity of the DMU to shift closer to or further away from the technological frontier from one time period to the next. Whereas, $F C_{0}^{t, t+1}$ (technological change index) equals changes in the efficient frontier relative to the DMU in two time periods and is usually associated with capital investment and long-term planning strategies.

The DEA was adopted for the study since it does not require a priori assumption of functional specification relating inputs to outputs and does not demand for the distributional assumption of the error term.

\subsection{Data and Variables}

The population of the study constitutes the over 110 pharma-formulation manufacturing facilities in Nigeria (Business Monitor International, 2009). The sample size consists of twenty (20) pharmaceutical companies (Afrab Chem. Limited, Archy Pharma Nigeria Ltd., Drugfield Pharmaceuticals Ltd, Ecomed Pharma Ltd., Emzor Pharmaceutical Industries Ltd, Evans Medical Plc, Fidson Healthcare Plc, Gemini Pharmaceuticals Nig. Ltd., GlaxoSmithKline Nigeria, Juhel Pharma., Enugu, May \& Baker Nigeria Plc, Mopson Pharmaceutical Industries Ltd, Neimeth International Pharmaceuticals, Nigerian-German Chemicals Plc, PZ Cussons Plc, 
Ranbaxy Nig. Ltd., Lagos, SKG Pharma Plc., Lagos, Swipha Nigeria Ltd, Swiss Pharma Nig. Ltd, Lagos, and Vitabiotics Nigeria Ltd) listed on the Nigeria Stock Exchange between 2012 and 2016. The selection of the sample was based on availability of a complete panel data between 2012 and 2016. Other firms had incomplete data or their data was unavailable in the years under consideration.

Secondary data of sales, size (measured by fixed assets), leverage (proxied by Total Liabilities divided by Total Asset), age of firm (measured by difference between current year and year of listing), Operating Expenses (sum of Selling expenses, Distribution cost, Marketing cost, Administrative expenses, Staff cost and Depreciation and amortization in thousands), Cost of sales (Beginning inventory, plus Purchases, less Ending inventory), Market share (sales over the period and dividing it by the total sales of the industry over the same period), Firm size (total sales in constant U.S. dollars), Export performance (Exports as a percentage of total sales), and Sales growth (measured by difference between current and previous year sales) were extracted from the Annual Reports and Accounts of the selected companies.

\subsection{Results and Discussion}

\subsection{Descriptive Results}

Table 1 shows the descriptive statistics of the variables employed in the study. A critical view of the table shows that efficiency scores were calculated using one output variable and three input variables, and as specified in the model, there were six variables (independent) to measure how firm-specific factors impact on the efficiency of the employed pharmaceutical firms. 
Table 1: Descriptive Statistics

\begin{tabular}{llcccc}
\hline Variable & & Mean & Maximum & Minimum & Std. Dev. \\
\hline $\begin{array}{l}\text { Output } \\
\text { Variable }\end{array}$ & Sales & 2037132.0 & 69558217.0 & 6942.0 & 3528531.0 \\
& & & & & \\
Input & Cost of Sales & 1083542.0 & 63428932.0 & 7037.0 & 2492351.0 \\
Variables & Operating & 92354.6 & 5245923.0 & 683.0 & 215476.7 \\
& Expenses & 1834537.0 & 42783593.0 & 21914.0 & 2157915.0 \\
& Capital & 13.3900 & 47.0000 & 5.0000 & 5.9327 \\
& Age & 0.2573 & 3.9000 & 0.0000 & 0.1945 \\
Independent & Exports Perf. & 0.0372 & 1.3007 & 0.0001 & 0.1152 \\
Variable & Leverage & 0.0201 & 0.0535 & 0.0000 & 0.0117 \\
& Market share & 9.2205 & 16.0900 & 11.3700 & 1.0342 \\
& Size & 0.1037 & 4.0362 & 0.0073 & 0.4903 \\
Dependent & Sales Growth & & & & \\
Variables & Technical & & & & \\
& Efficiency & 0.6473 & 1.0000 & 0.0750 & 0.1140 \\
& (CRS) & & & & \\
& Technical & & & & \\
& Efficiency & 0.6103 & 1.0000 & 0.1010 & 0.1038 \\
& (VRS) & & & & \\
\end{tabular}

The average age of pharmaceutical firms in Nigeria was observed to be about 13 years. The table showed that the Nigerian pharmaceutical sector exports about $26 \%$ of its produce. These exports are majorly to the ECOWAS countries. The financial strength of the pharmaceutical sector, as captured by the average leverage ratio, was approximately $3.7 \%$. This is generally low, and it calls for more financing in this sector. The average market share from the table was $2 \%$ since the industry has many players. The average sales growth is approximately $10 \%$. This calls for swift attention in the Nigerian pharmaceutical sector. The average values of the technical efficiency under CRS and VRS assumptions which are 0.64734 and 0.61034, respectively, shows that the pharmaceutical sector in Nigeria is relatively less efficient and shows that there is need to improve the sector.

\subsection{Unit Root Test}

The first econometric requirement for estimating a model is that the variables to be used must be stationary $I(0)$ series. Before testing if the series follow a unit root, we checked the possibility of cross-sectional dependence in the series which will likely invalidate the unit root tests. The results obtained from the cross-sectional dependence (CD) test of Pesaran (2004) are shown below. 
Table 2: Cross-sectional dependence (CD) test

\begin{tabular}{lcc}
\hline \multicolumn{1}{c}{ Variable } & CD statistics & p-value \\
\hline Sales & $31.37^{* *}$ & 0.00 \\
Cost of sales & $29.33^{* *}$ & 0.00 \\
Operating expenses & $61.02^{* *}$ & 0.00 \\
Capital & $47.71^{* *}$ & 0.00 \\
Age & $16.91^{* *}$ & 0.00 \\
Exports perf. & $79.39^{* *}$ & 0.00 \\
Leverage & $63.97^{* *}$ & 0.00 \\
Market share & $30.06^{* *}$ & 0.00 \\
Size & $43.77^{* *}$ & 0.00 \\
Sales growth & $27.61^{* *}$ & 0.00 \\
\hline
\end{tabular}

$* *$ denotes rejection at the $5 \%$ level

From Table 2, the null hypothesis of no cross-sectional dependence can be strongly rejected given that the $\mathrm{p}$-value $=0$ for all the variables. In the light of this, we applied the cross-sectionally Augmented Dickey-Fuller (CADF) and cross-sectionally Im-Pesaran-Shin (CIPS) as proposed by Im, et al. (1995) and Harnsen (1995), respectively. The results from these are presented below.

Table 3: Unit root test

\begin{tabular}{lcccc}
\hline \multirow{2}{*}{ Variables } & \multicolumn{2}{c}{ CADF } & \multicolumn{2}{c}{ CIPS } \\
\cline { 2 - 5 } & Level & $\begin{array}{c}\text { First } \\
\text { difference }\end{array}$ & Level & $\begin{array}{c}\text { First } \\
\text { difference }\end{array}$ \\
\hline Sales & -1.41 & $-3.31^{* *}$ & -1.13 & $-2.88^{* *}$ \\
Cost of sales & -0.73 & $-3.07^{* *}$ & -0.72 & $-3.92^{* *}$ \\
Operating expenses & -0.97 & $-2.77^{* *}$ & -0.21 & $-4.01^{* *}$ \\
Capital & -1.17 & $-2.27^{* *}$ & -1.51 & $-3.05^{* *}$ \\
Age & -1.26 & $-3.51^{* *}$ & -1.07 & $-2.69^{* *}$ \\
Exports perf. & -1.08 & $-3.22^{* *}$ & -0.28 & $-3.08^{* *}$ \\
Leverage & -0.33 & $-2.86^{* *}$ & -0.11 & $-3.37^{* *}$ \\
Market share & -0.21 & $-3.17^{* *}$ & -1.72 & $-4.10^{* *}$ \\
Size & -1.78 & $-3.95^{* *}$ & -0.09 & $-3.25^{* *}$ \\
Sales growth & -1.07 & $-4.21^{* *}$ & -1.02 & $-3.87^{* *}$ \\
\hline$* *$ denotes rejection at $5 \%$ level & & &
\end{tabular}

The unit root test results shown above indicate that the variables are $I(1)$ processes. Thus, they were utilized in their first differences.

\subsection{Data Envelopment Analysis}

Table 4 shows a year-to-year analysis of the various perspectives of efficiency as well as averages under the CRS and VRS assumptions between 2012 and 2016. It 
also reports the various efficiency changes which include Scale Efficiency Change, Pure Efficiency Change and Technical Efficiency Change. The averages in the CRS and VRS assumptions show irregular patterns in the movement of efficiency in the pharmaceutical sector, with spiral oscillations from year-to-year. From the table, the SECH (scale efficiency change) shows an average of 0.9558 . This value implies that the pharmaceutical sector in Nigeria is experiencing a decreasing return to scale in the period under consideration, since the coefficient value of SECH is less than 1. A decreasing return to scale is also observed in the variable TECH (technical efficiency change). The averages of PECH, EFFCH and TFPCH were 1.0425, 1.1745 and 1.1478 respectively. These values indicated that the pharmaceutical sector experienced an increasing return to scale during the 2012-2016 period. A critical analysis of the various efficiency changes shows that inefficiency experienced in the pharmaceutical sector is scalar in nature (in other words, scale efficiency).

Table 4: Data envelopment analysis results

\begin{tabular}{cccccccc}
\hline Years & EFFCH & TECHCH & PECH & SECH & TFPCH & TE(CRS) & TE(VRS) \\
\hline 2012 & - & - & - & - & - & 0.64 & 0.604 \\
2013 & 0.723 & 0.792 & 1.207 & 1.105 & 1.051 & 0.522 & 0.715 \\
2014 & 1.421 & 1.386 & 0.733 & 0.965 & 0.814 & 0.627 & 0.663 \\
2015 & 0.673 & 0.759 & 1.022 & 1.072 & 1.703 & 0.609 & 0.739 \\
2016 & 1.881 & 1.006 & 1.211 & 0.681 & 1.023 & 0.191 & 0.1 \\
Averages & 1.1745 & 0.9858 & 1.0425 & 0.9558 & 1.1478 & 0.6473 & 0.6103 \\
\hline
\end{tabular}

\subsection{Conclusion and Policy Implications}

Performance analysis constitutes a major objective of any organization. Owing to this, the purpose of this study was to assess the efficiency of the pharmaceutical sector in Nigeria. Employing sales as output variable; cost of sales, operating expenses, and capital as input variables; and age of firm, exports performance, leverage, market share, firm size, and sales growth as independent variables, the study found oscillatory movements observed under the CRS and VRS assumptions from year-to-year. Scale efficiency change and technical efficiency change both experienced a decreasing return to scale indicating an urgent need to address the issue of efficiency in the pharmaceutical sector.

Given the low penetration of Nigerian pharmaceuticals in the global market, there is need to improve on the quality and standard of the pharmaceutical sector in 
Nigeria so as to meet up with internationally-accepted standards to facilitate participation and competition with countries such as China, India, Turkey and others. This is imperative given the negative coefficient of export performance under both the CRS and VRS assumptions. There is also need to increase financial support to the sector to aid with technological advancement.

Drawing from the efficiency issues in the Nigerian pharmaceutical industry, the sector should be reformed and revamped. Governmental health agencies such as the Federal Ministry of Health, and other health authorities (Pharmacists' Council of Nigeria (PCN), Pharmaceutical Manufacturing Group of Manufacturers' Association of Nigeria National Agency for Food and Drug Administration and Control (NAFDAC)) should reduce registration and administrative costs for pharmaceutical firms operating in Nigeria. This will allow local firms to produce quality medicines that can compete internationally. This can be done via improved biotechnology and development of new phytomedicines using locally sourced raw materials which requires a sizeable investment in Research and Development.

\section{References}

Adhikari, A. (2005). SCP vs. Efficiency approach: An empirical analysis of Indian pharmaceutical industry. Punjagutta: icfai University Press.

Aristovnik, A., Seljak, J. and Mencinger, J. (2014). Performance measurement of police forces at the local level: A non-parametric mathematical programming approach. Expert Syst. Appl. Vol. 41, pp. 1647-1653.

Azadeh, A., Motevali, S., Zarrin, M. and Khae, S. (2015). Performance evaluation of Iranian electricity distribution units by using stochastic data envelopment analysis. Int. J. Electr. Power Vol. 73, pp. 919-931.

Behname, M. (2012). The compare of concentration and efficiency in banking industry: Evidence from the OPEC countries. Eurasian Journal of Business and Economics, Vol. 5 No. 10, pp. 15-24.

Berger, A. N. (1995). The profit-structure relationship in banking-tests of marketpower and efficient-structure hypotheses. Journal of Money, Credit, and Banking, Vol. 27 No. 2, pp. 404-31.

Brozen, Y. (1982). Concentration, mergers and public policy. New York: Macmillan. 
Business Monitor International. (2009). Nigerian pharmaceutical industry report. Business Monitor International, London.

Business Monitor International (2010). Nigeria pharmaceuticals and healthcare report Q4 2010. BMI, London.

Chadda, A. (2006). Destination India - the right choice for the pharmaceutical industry, Delhi Business Review, Vol. 7 No. 1, pp. 1-8.

Charnes, A., Cooper, W.W. and Rhodes, E. (1978) Measuring the efficiency of decision-making units. European Journal of Operation Research, Vol. 2, pp. $429-444$.

Chaturvedi, K. and Chataway, J. (2006). Innovation in the post-trips regime in Indian pharmaceutical firms: Implications for pharmaceutical innovation model, International Journal of Business Innovation and Research, Vol.1 (1-2).

Cockburn, I.M. (2004). The changing structure of the pharmaceutical industry, Health Affairs, Vol. 23 No. 1, pp. 10-22.

Coelli, T., Rao, D. S. P., O’Donnell, C. J. and Battese, G. E. (2005). An introduction to efficiency and productivity analysis, New York: Springer Press.

Demsetz, H. (1973). Industry structure, market rivalry and public policy. Journal of Law and Economics Vol. 16 No. 1, pp. 1-9.

Du, J., Cook, W.D., Liang, L. and Zhu, J. (2014). Fixed cost and resource allocation based on DEA cross-efficiency. European Journal Operations Research , Vol. 235, pp. 206-214.

Fang, L. and Li, H. (2015). Centralized resource allocation based on the costrevenue analysis. Comput. Ind. Eng. Vol. 85, pp. 395-401.

Fare, R., Grosskopf, S., Norris, M., and Zhang, Z. (1994). Productivity growth, technical progress, and efficiency change in industrialized countries. Am. Econ. Rev. Vol. 84, pp. 66-83.

Farrell, M.J. (1957). The measurement of productive efficiency. J. R. Stat. Soc.A Stat., Vol. 120, pp. 253-290.

Ferreira, C. (2014). Panel granger causality between bank efficiency and market concentration in the European Union. Research in Applied Economics, Vol. 6 No. 1.

Gale, B. T., and Branch. B. S. (1982). Concentration versus market share: which determines performance and why does it matter? Antitrust Bulletin. Vol. 27, pp. 83-106. 
Giroh, D. Y., Umar, H. Y. and Yakub, W. (2010). Structure conduct and performance of farm gate marketing of natural rubber in Edo and Delta States, Nigeria, African Journal of Agricultural Research, Vol. 5 No. 14, pp. 17801783.

Gupta, D. B., (2007), Exciting opportunities for the Indian pharmaceutical industry, Indian Chemical Engineer, Vol. 49 No. 2, pp. 154-157

Harnsen, B.E., (1995). Rethinking the univariate approach to unit root testing: using covariates to increase power, Econometric Theory, Vol. 11, pp. 11481171.

Howard, T., and Pollock. T. (1999). From industrial economics' SCP paradigm through strategic groups to competence-based competition: reflections on the puzzle of competitive strategy. British Journal of Management, Vol. 10, pp. 127-40.

Im, K., Pesaran, H., and Shin, Y. (1995). Testing for unit roots in heterogeneous panels, DAE Working Papers Amalgamated Series No. 9526, University of Cambridge.

Jiankang, M. U. (2014). SCP analysis of biopharmaceutical industry in China. Journal of Chemical and Pharmaceutical Research Vol. 6 No. 3, pp. 522-9.

Kumar, S. and Gulati, R. (2008). An examination of technical, pure technical, and scale efficiencies in Indian public sector banks using data envelopment analysis. Eurasian J. Bus. Econ. Vol. 1, pp. 33-69.

Kwon, H.B. and Lee, J. (2015) Two-stage production modeling of large U.S. banks: A DEA-neural network approach. Expert Syst. Appl. Vol. 42, pp. 6758-6766.

Lead Capital Limited (2008). Nigeria's pharmaceutical and health care sector: a critical analysis, in Lynch, R (1997). Corporate Strategy, London: Pitman Publishing

Lee C.C (2012). The causal correlations among market structure, conduct and performance of the CPA industry. The Service Industries Journal, Vol. 32 No. 3, pp. 431-450.

Lozano, S. A joint-inputs network (2015). DEA approach to production and pollution-generating technologies. Expert Syst. Appl. Vol. 42, pp. 79607968.

Maniatis, P. (2006). Market concentration and industry profitability: The case of Greek banking (1997-2004). International Business and Economics Research Journal, Vol. 5 No. 10. 
Mari, F. M. (2009). Structure and efficiency analysis of vegetable production and marketing in Sindh, Pakistan, Unpublished Ph.D Thesis, Department of Agricultural Economics, Faculty of Agricultural Social Sciences, Sindh, Agriculture University, Tandojam.

Maudos, J. (1998). Market structure and performance in Spanish banking using a direct measure of efficiency. Applied Financial Economics, Vol. 8, pp. 191-200.

Mensi, S. and Zouari, A. (2011). Banking industry, market structure and efficiency: the revisited model to intermediary hypotheses. International Journal of Economic Research, Vol. 2 No. 1, pp. 23-36.

Mishra, P. and Chandra, T. (2010). Mergers, acquisitions and firms' performance: experience of Indian pharmaceutical industry. Eurasian Journal of Business and Economics, Vol. 3 No. 5, pp. 111-126.

Mishra, P. and Vikas, R. (2010). Structure, conduct and performance in Indian pharmaceutical industry: A simultaneous equations investigation. Review of Development and Change, Vol. 15 No. 1, pp. 69-99.

Ogaji J. K, Alawode A. O and Iranloye T. A. (2014). Pharmaceutical industry capacity utilization in Nigeria, African Journal of Pharmacy and Pharmacology, Vol. 8 No. 21, pp. 579-585

Olugbenga, J. (2010). An appraisal of the relationship between working capital and liquid Assets of Nigerian companies: A comparative study of then selected companies. Journal of research in National development, Vol. 8 No. 1.

Omrani, H., Gharizadeh, R. and Shafei, S. (2015). Performance assessment of Iranian electricity distribution companies by an integrated cooperative game data envelopment analysis principal component analysis approach. International Journal of Electrical Power and Energy Systems, Vol. 64, pp. 617-625. DOI: $10.1016 /$ j.ijepes.2014.07.045

Park, K.H. (2012). Bank mergers and competition in Japan. International Journal of Banking and Finance, Vol. 9 No. 2, pp. 1-25.

Pharmaceutical Manufacturing Group of Manufacturers' Association of Nigeria. (2010). Report on the status of Nigerian pharmaceutical industry. Pharmaceutical Manufacturing Group of Manufacturers' Association of Nigeria, Lagos.

Praveen, K., and Tapan K. N. (2005). The SCP paradigm and its relevance to the Indian industry. The IUP Journal of Industrial Economics, Vol. 2 No. 2, pp. 7-20. 
Sahoo, D. and Mishra, P. (2012). Structure, conduct and performance of Indian banking sector. Review of Economic Perspectives, Vol. 12 No. 4, pp. 235264.

Sarita, B., Zandi, G., and Shahabi, A. (2012). Determination of performance in Indonesian banking: A cross-sectional and dynamic panel data analysis. International Journal of Economics and Finance Studies, , Vol. 4 No. 2.

Shaik, S., Allen, A.J., Edwards.S. and Harris, J. (2009). Market structure conduct and performance hypothesis revisited using stochastic frontier efficiency analysis. Journal of Transportation Research Forum, Vol. 48 No. 3, pp. 518.

Tao, L., Liu, X. and Chen, Y. (2013). Online banking performance evaluation using data envelopment analysis and axiomatic fuzzy set clustering. Qual. Quant. , Vol. 47, pp. 1259-1273.

Tsolas, I.E. and Charles, V. (2015). Incorporating risk into bank efficiency: A satisficing DEA approach to assess the Greek banking crisis. Expert Syst. Appl. , Vol. 42, pp. 3491-3500.

Tung, G.S., C.Y. Lin, and Wang. C.Y. (2010). The market structure, conduct and performance paradigm re-applied to the international tourist hotel industry, African Journal of Business Management Vol. 4 No. 6, pp. 1116 -1125 .

Ugbam O.C. and Okoro E.A. (2017). A strategic study of the Nigerian pharmaceutical sector: Organizational leadership, market-share, and competitive performance, International Journal of Business, Humanities and Technology, Vol. 7 No. 1, pp. 1-10.

Vyas, V., Narayanan, K., and Ramanathan, A. (2012). Determinants of mergers and acquisitions in Indian pharmaceutical industry. Eurasian Journal of Business and Economics, Vol. 5 No. 9: pp. 79-102.

Wakeel A.I. and Ekundayo, P.M. (2016). Determinants of pharmaceutical industry's performance in Nigeria, Managing Global Transitions, Vol. 14 No. 3, pp. $267-282$.

Wanke, P. and Barros, C. (2014). Two-stage DEA: An application to major Brazilian banks. Expert Syst. Appl. Vol. 41, pp. 2337-2344.

World Health Organization (2000). World report, New York

World Health Organization (2013). World report, New York

World Health Organization (2014). Drug information, Vol. 28 No. 4 
Zhang Y.C. and Li S.L. (2009). High performance work practices and firm performance: Evidence from the pharmaceutical industry in China. The International Journal of Human Resource Management, Vol. 20 No. 11, pp. 2331-2348.

Zhu, J. (2002). Quantitative models for performance evaluation and benchmarking: data envelopment analysis with spreadsheets and DEA excel solver, Kluwer Academic Publishers, Boston. 